\title{
Level of Recycling Awareness and Responses to On-campus Recycling Facilities: Case Study-Universiti Kebangsaan Malaysia Students
}

\author{
Kian-ghee Tiew ${ }^{1}$, Kohei Watanabe ${ }^{2}$, Noor Ezlin Ahmad Basri ${ }^{1}$, Shahrom Md. Zain ${ }^{1} \&$ Hassan Basri $^{1}$
}

\begin{abstract}
A survey to find out the level of recycling awareness of 400 students at Universiti Kebangsaan Malaysia (UKM), Bangi was conducted. The written questionnaires were focused on evaluation of waste management in UKM, recycling awareness and effective recycling bins design in UKM. The recycling facility was generally well supported, with predominantly positive recycling attitudes and self-reported recycling behaviour indicated for students. As conclusion, the survey conducted shows that the students are ready for recycling activities if the recycling facilities are provided and accessible to them.
\end{abstract}

Keywords: Recycling, 3R, Awareness, 2 bins system, campus, University

\section{INTRODUCTION}

$\mathrm{U}$ niversiti Kebangsaan Malaysia (UKM) is one of the Malaysia's leading universities having a campus population of approximately 30,000, comprising of lecturers and students. Because of the large size of this community, solid waste management represents one of the greatest challenges for achieving institutional sustainability.

In 2008, a major change took place in the solid waste management (SWM) system in the university. A Memorandum of Agreement (MoA) was signed to upgrade the solid waste collection to a centralized collection system through the collaboration between UKM and a solid waste company, Alam Flora Sdn Bhd (AFSB). The collaboration was intended to institute an integrated solid waste management (ISWM) at the university and to enable the university to achieve its Zero-Waste campus objective. The rate of solid waste generation by the university was recently estimated to be approximately 8 ton per day [1].

In early January 2011, 2-bins system was established in UKM where the bins for recycling and residual waste were located in UKM campus at corridors of the centres, institute and faculties. 2-bins system is a cost effective method and an easy access of recycling facility that can get the community in the campus to involve in the solid waste separation. The elements of 3R concept (reduce, re-use and recycle) are the main key in the waste management hierarchy which is a vital factor towards zero waste campus [ $2 \& 3]$. Hence, public participation and responsible behavior are the main elements to ensure a successful recycling programme rather than depending on technology [4]. Furthermore, recycling awareness at campus level is important because university is a place where future leaders of the society are produced. The objective of this study was to assess the level of recycling awareness and response to on-campus recycling facility in order to improve the recycling system in UKM.

Kian-ghee Tiew. Department of Civil and Structural Engineering, Faculty of Engineering and Built Environmental, Universiti Kebangsaan Malaysia(corresponding author: 6016-254-2998; fax: 603-8921-6147; e-mail: tiew8585@ yahoo.com).

Noor Ezlin Ahmad Basri, Shahrom Md. Zain \& Hassan Basri. Department of Civil and Structural Engineering, Faculty of Engineering and Built Environmental, Universiti Kebangsaan Malaysia.( E-mail: ezlin@vlsi.eng.ukm.my, smz@vlsi.eng.ukm.my \& drhb@vlsi.eng.ukm.my)

Kohei Watanabe. Institute for Environment and Development (LESTARI), Universiti Kebangsaan Malaysia and Teikyo University

UKM Bangi, 43600, Selangor Darul Ehsan, Malaysia.( kw10004@ cam.ac.uk) 


\section{Methods}

Table 1 shows the locations and quantities of 2-bins system throughout UKM. A written 3-page questionnaire was developed, which comprised of four sections: (A) background of respondent; (B) waste management in UKM; (C) recycling and awareness knowledge of respondent; and (D) design of effective bins in UKM. Responses were indicated via tick boxes and Guttman scales, with spaces for written comments provided.

Table 1 Locations of 2-bins system in campus UKM

\begin{tabular}{|c|c|c|}
\hline No & Locations & Quantity of Recycle bins \\
\hline 1 & Chancellery Building & 9 \\
\hline 2 & Dewan Canselor Tun Abdul Razak [DECTAR] & 3 \\
\hline 3 & Dewan Gemilang & 4 \\
\hline 4 & Faculty of Economics and Management & 6 \\
\hline 5 & Faculty of Science and Technology & 27 \\
\hline 6 & Faculty of Social Sciences and Humanities & 18 \\
\hline 7 & Faculty of Islamic Studies & 7 \\
\hline 8 & Faculty of Science and Technology - Science Nuclear Building & 10 \\
\hline 9 & Faculty of Engineering and Built Environment & 50 \\
\hline 10 & Faculty of Education & 33 \\
\hline 11 & Faculty of Law & 21 \\
\hline 12 & Faculty of Information Science and Technology & 30 \\
\hline 13 & Centre for Student Health & 10 \\
\hline 14 & Centre for Research and Innovation Management & 9 \\
\hline 15 & Centre for Language Studies and Linguistics [FSSK] & 15 \\
\hline 16 & Centre for Information Technology & 6 \\
\hline 17 & Centre for General Studies & 3 \\
\hline 18 & Centre for Earth Observation & 2 \\
\hline 19 & Centre for Academic Advancement & 3 \\
\hline 20 & Centre for UKM Publisher & 6 \\
\hline 21 & PPS/IKMAS/LESTARI Building & 8 \\
\hline 22 & INBIOSIS Building & 3 \\
\hline 23 & Institute of The Malay World and Civilisation [ATMA] & 3 \\
\hline 24 & Pusanika (Student Centre) & 3 \\
\hline 25 & Tun Seri Lanang Library & 3 \\
\hline 26 & Department of Development Management & 3 \\
\hline 27 & UKM Pakarunding Sdn Bhd (Consultancy and Research) & 3 \\
\hline \multirow[t]{2}{*}{28} & UNIKEB Building & 5 \\
\hline & Total & 303 \\
\hline
\end{tabular}

A sample of 400 students was randomly selected from an estimated total campus population of 20,000 students. According to Mitchell and Jolley [5], 377 samples is a minimum sample size required for 20,000 populations. The Pearson Chi-square test for independence was utilised to examine the significance of interdependence between male and female. Significant interdependence was further examined using correspondence analysis [6 \& 7]. Statistical analysis was carried out using PASW (Predictive Analytics SoftWare). 


\section{RESUlTS AND DISCUSSIONS}

The total number of respondents was 400 students (164 male and 236 female). They were randomly selected for the survey. Respondents' background and characteristics are as shown in Table 2 and Figure 1.

Table 2 Respondent's background between male and female

\begin{tabular}{|c|c|c|c|}
\hline Characteristics & Male & Female & Total \\
\hline \multicolumn{4}{|l|}{ Faculty of Respondents } \\
\hline Faculty of Economics and Management & $10.4 \%$ & $11.0 \%$ & $11.5 \%$ \\
\hline Faculty of Engineering and Built Environment & $13.4 \%$ & $13.7 \%$ & $14.5 \%$ \\
\hline Faculty of Education & $15.2 \%$ & $19.0 \%$ & $18.8 \%$ \\
\hline Faculty of Islamic Studies & $11.0 \%$ & $3.8 \%$ & $7.0 \%$ \\
\hline Faculty of Social Sciences and Humanities & $12.2 \%$ & $17.9 \%$ & $16.8 \%$ \\
\hline Faculty of Science and Technology & $17.7 \%$ & $20.9 \%$ & $21.0 \%$ \\
\hline Faculty of Information Science and Technology & $8.5 \%$ & $1.5 \%$ & $4.5 \%$ \\
\hline Faculty of Law & $11.6 \%$ & $1.1 \%$ & $5.5 \%$ \\
\hline LESTARI & $0.0 \%$ & $0.8 \%$ & $0.5 \%$ \\
\hline
\end{tabular}

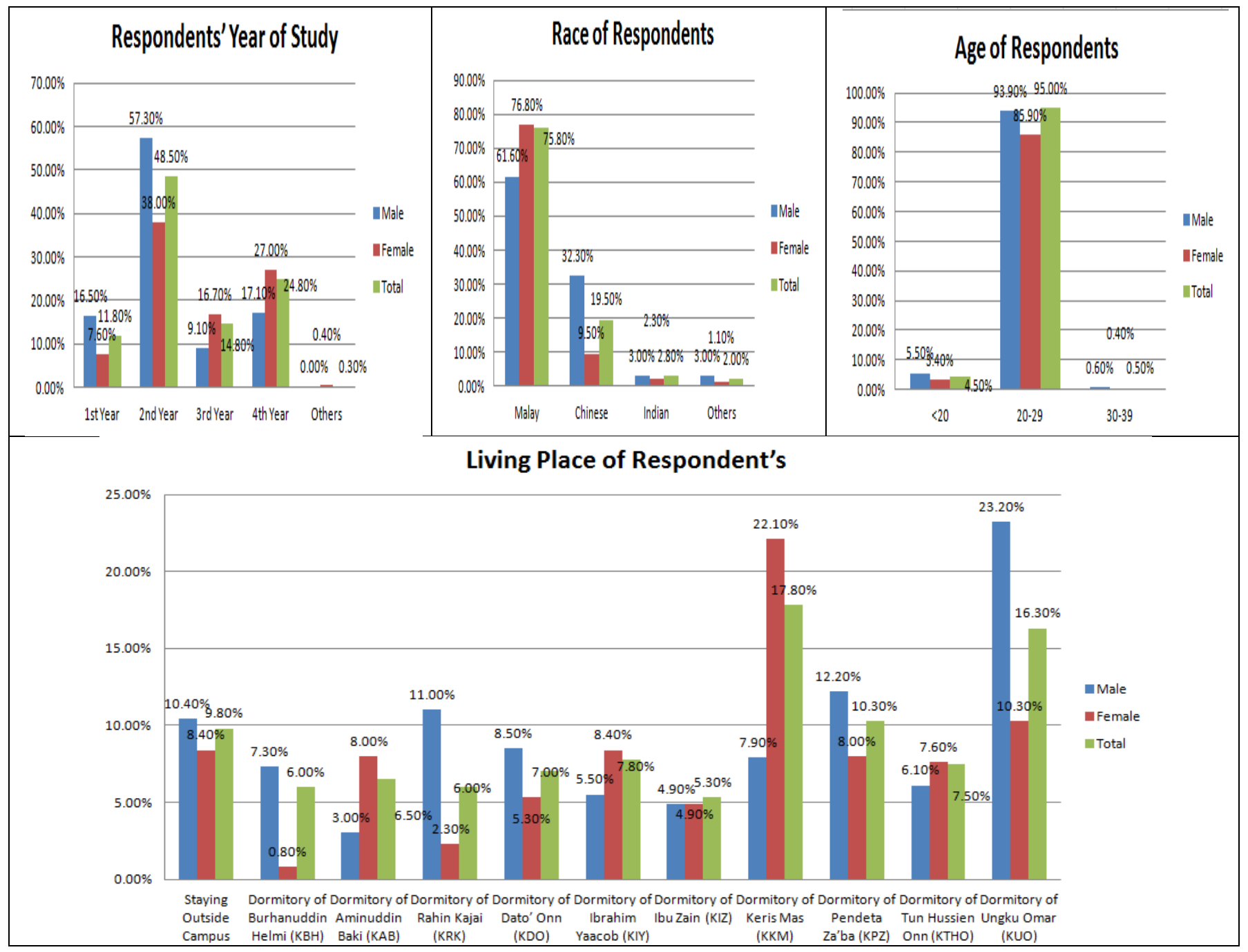

Figure 1 Respondent's characteristics between male and female 
Results for the satisfaction of the solid waste management in UKM (Part B) are shown in Table 3.

Table 3 Results questionnaire Section B (Waste Management in UKM)

\begin{tabular}{llcc}
\hline & \multicolumn{1}{c}{ Questions } & Answer & Number of Respondents \\
\hline \multirow{2}{*}{ B1 } & $\begin{array}{l}\text { Are you satisfied with waste collection systems around you } \\
\text { (for example in the colleges, cafeteria \& faculty)? }\end{array}$ & Yes & 177 \\
& & No & 159 \\
B2 & Not Sure & 64 \\
and compatible with the requirements of UKM today? & Yes & 170 \\
& & Not Sure & 139 \\
B3 In your observation, how many times in a week is trash in & $0-2$ times & $3-5$ times & 218 \\
& your environment has been overflow (count in day)? & $5-7$ times & 158 \\
& Foul odor, waste scattered on the floor, waste water and & Rarely & 24 \\
B4 & breeding of flies are a common phenomenon in your & Average & 202 \\
& neighbourhood? & Often & 134 \\
B5 & Estimated average amount of waste you generate each day. & $0.6 \mathrm{~kg} / \mathrm{day}$ & 64 \\
& & $>0.6 \mathrm{~kg} / \mathrm{day}$ & 265 \\
\hline
\end{tabular}

Question B1 was to identify the satisfaction of the waste collection systems in UKM. The results showed $44.3 \%$ of the students were satisfied with the collection system in UKM, while $39.7 \%$ students were not satisfied with the present system of waste collection and $16.0 \%$ were not sure of their satisfaction on the waste collection systems in UKM. P value for the Pearson Chi Square test was 0.637 , where p> 0.05 indicates that there is no significant difference in satisfaction of the waste collection system between male and female students.

For question B2, $42.5 \%$ of the students thought positively of the collection system in UKM at present, while $34.8 \%$ of the students did not believe the collection system is efficient, and $22.7 \%$ of the students were not sure of the efficiency of the collection system. P value for the Pearson Chi Square test was 0.579 , where there was no significant difference between male and female students' responses on the waste collection system at this present time.

In addition, question B3 showed the students' observations on the overflow of garbage bins 0-2 times a week were $54.5 \%, 3-5$ times per week was 39.5\%, and 5-7 times per week was 6\%. According to students' observations results show that at least 0-2 times a week garbage bins is overflow. Therefore, the measure to overcome this problem is to increase the number of bins in the place where there is always garbage overflow. P value for the Pearson Chi Square test was 0.035 where $\mathrm{p}<0.05$ indicates that there are significant differences between male and female students on the response to the abundant waste in the garbage house.

Furthermore, the results for question B4 showed 50.5\% of the students thought of garbage pollution in the UKM campus as rare, followed by $33.5 \%$ and $16.5 \%$ showed rates of contamination at garbage house are average and often respectively. Thus, the overall students believed that the rate of household waste pollution is satisfactory. $\mathrm{P}$ value for the Pearson Chi Square test was 0.885 which means there was no significant difference between males and females on the responses to the garbage house pollution.

Results indicated that in the question B5 $66.3 \%$ of the students estimated waste generation rate is less than 600 grams/day. While, $24.5 \%$ of students will generate around 600 grams/day solid waste and $9.3 \%$ of students will generate more than 600 grams of waste per day. P value for the Pearson Chi Square test was 0.929 which means there was no significant difference between males and females in the estimation of waste generation rate. 
The purpose of Part $\mathrm{C}$ was to investigate the awareness on the $3 \mathrm{R}$ concept of recycling among the students. Table 4 shows the results of respondents' questions.

Table 4 Results questionnaire Part C (Knowledge Recycling and the 3R concept of UKM)

\begin{tabular}{|c|c|c|c|}
\hline \multicolumn{2}{|r|}{ Questions } & Answer & Number of Respondents \\
\hline \multirow{3}{*}{$\mathrm{C} 1$} & \multirow{3}{*}{ Do you know what the $3 \mathrm{R}$ concept is? } & Yes & 287 \\
\hline & & No & 68 \\
\hline & & Not Sure & 45 \\
\hline \multirow{3}{*}{$\mathrm{C} 2$} & \multirow{3}{*}{$\begin{array}{l}\text { Did you know what 3R stands are for? } \\
\text { (choose one only) }\end{array}$} & Reduce; Reuse; Recycle & 250 \\
\hline & & Reuse; Reduce; Recycle & 55 \\
\hline & & Recycle; Reuse; Reduce & 95 \\
\hline \multirow{3}{*}{$\mathrm{C} 3$} & \multirow{3}{*}{ Do you recycle? } & Yes & 210 \\
\hline & & No & 136 \\
\hline & & Not Sure & 54 \\
\hline \multirow{5}{*}{$\mathrm{C} 4$} & \multirow{5}{*}{$\begin{array}{l}\text { How many times a month do you recycle } \\
\text { your recyclables? }\end{array}$} & 1 times & 175 \\
\hline & & 2 times & 72 \\
\hline & & 3 times & 17 \\
\hline & & $>3$ times & 24 \\
\hline & & Never & 112 \\
\hline \multirow{3}{*}{$\mathrm{C} 5$} & \multirow{3}{*}{$\begin{array}{l}\text { In your opinion, should the trash be } \\
\text { separated when you dispose it? }\end{array}$} & Yes & 387 \\
\hline & & No & 5 \\
\hline & & Not Sure & 8 \\
\hline \multirow[b]{2}{*}{ C6 } & \multirow{3}{*}{$\begin{array}{l}\text { Do you dispose the trash into the } \\
\text { appropriate bins and separate garbage for } \\
\text { recycling? }\end{array}$} & Yes & 254 \\
\hline & & No & 146 \\
\hline \multirow{4}{*}{$\mathrm{C} 7$} & & 2 bin & 24 \\
\hline & \multirow{3}{*}{$\begin{array}{l}\text { How many recycling bins that you think is } \\
\text { needed to provide? }\end{array}$} & 3 bin & 268 \\
\hline & & 4 bin & 88 \\
\hline & & 5 bin & 20 \\
\hline \multirow{3}{*}{$\mathrm{C} 8$} & \multirow{3}{*}{$\begin{array}{c}\text { Will you dispose waste into the appropriate } \\
\text { bins if the system } 2 \text { or } 3 \text { bins system is } \\
\text { implemented in UKM? }\end{array}$} & Yes & 354 \\
\hline & & No & 18 \\
\hline & & Not Sure & 28 \\
\hline
\end{tabular}

Results for question $\mathrm{C} 1$ show a total of $71.8 \%$ students understood the concept of $3 \mathrm{R}$. Meanwhile, $17.0 \%$ of the students did not know the concept of $3 \mathrm{R}$ and $11.2 \%$ were not sure of the purpose of the 3R concept. The result shows that many students may have learned the $3 \mathrm{R}$ concept through newspapers and publications from government. P value for the Pearson Chi Square test was 0.330 , hence, there was no significant difference between male and female students on the $3 \mathrm{R}$ concept.

For question $\mathrm{C} 2,62.5 \%$ of the students knew the correct order of 3R. This question was to ensure that students know clearly the concept of $3 \mathrm{R}$ and its function. P value for the Pearson Chi Square test was 0.217 which means there was no significant difference between male and female students on the response to the composition of the $3 \mathrm{R}$ concept. In addition, the $P$ value for the Pearson Chi Square test was 0.003 which means there are significant differences between the $3 R$ concept $(C 1)$ and arrangement of $3 \mathrm{R}$ structure $(\mathrm{C} 2)$. On the other hands, students that claim to understand the 3R concept tend to choose the correct answer. However there are also a small number of students who think they know the $3 \mathrm{R}$ concept but answered the wrong priority order. Hence, UKM management should take some action to having green campaign to educate and enhance important of $3 \mathrm{R}$ concept among the students.

Results for question C3 showed that about $52.5 \%$ of the students will carry out the recycling, whereas, $34.0 \%$ of the students will not carry out recycling activities on the grounds that there was no time and no recycling facilities. Furthermore, $13.5 \%$ were not sure whether to carry out recycling activities or not. P value for the Pearson Chi Square test was 0.397 which means there was no significant difference between male and female students to carry out recycling activities.

In addition, question $\mathrm{C} 4$ shows that a total of $43.8 \%$ of the students carried out at least 1 time the recycling activities in each month followed by $18 \%$ of the students who had 2 times the recycling per month, $4.2 \%$ of the students ran 3 times recycling per month, $6 \%$ of students exceeded three times and $28 \%$ never carried out recycling activities. $\mathrm{P}$ value for the Pearson Chi Square test was 0.840 which means there was no significant difference between males and females on the frequency of recycling activities.

Results of C5 question indicated that $96.8 \%$ of the students will separate waste at source. Meanwhile, $1.3 \%$ of the students will not separate waste at source and $2.0 \%$ were not sure of the separate waste at source. The results show that the 
students are willing to start waste separation at source if recycling facilities provided. P value for the Pearson Chi Square test was 0.136 which means there was no significant difference between males and females on the opinion to separate waste at source.

In addition, the results of question C6 show a total of $63.5 \%$ will separate waste at source with the facilities available, while $36.5 \%$ thought not to separate waste at source even if facilities are provided. P value for the Pearson Chi Square test was 0.022 which means there are significant differences between males and females and females is more towards to separate waste at source with the facilities provided. Next, the value of $\mathrm{P}$ for Pearson Chi Square test was 0.072 which means there is no significant difference between the willingness separation waste at source and separation waste at source with the recycling facilities provided.

Question C7 showed that about 67\% of the students suggested of providing 3-bins recycle bins. This is because the Malaysian public has been familiar with the concept of 3-recycling bins that have been implemented by the government since 2000 [8]. However, the results of the use of 2-bins and 3-bins that have been carried out in the UKM show the percentage of wrong usage of the 3-bins is higher than the 2-bins. Thus, the time of initial separation of waste at the source of 2-bins system is more suitable to be implemented. P value for the Pearson Chi Square test was 0.168 which means there was no significant difference between males and females on the number of recycling bins to be provided to carry out recycling activities.

Results of question C8 showed a positive response from about 88.5\% UKM students will separate waste if recycling facilities are provided such as 2-bins or 3-bins recycle bins are available in the UKM. P value for the Pearson Chi Square test was 0.931 which means there was no significant difference between males and females in their opinion to separate waste at source with the ease 2-bins and 3-bins.

\section{c) Design of effectiveness bins in UKM}

Indent D is to study design of effective bins in UKM on the students' perception. Results of question D1 showed that $82 \%$ of the students will open and close the lid during the process of trash removal, while the remaining $14.5 \%$ of those students will not open and close the trash can lid and 3.5\% of the students were not sure. P value for the Pearson Chi Square test was 0.309 which means there was no significant difference between boys and girls to open and close the cover while removing waste bins.

In addition, according to the results of question D4, 91\% of the students agreed with the sample design of recycling bins as in Figure 2. Meanwhile, $9 \%$ of students disagreed with the sample design of the proposed recycling bins. P value for the Pearson Chi Square test was 0.932 which means there was no significant difference between male and female students on the sample design recycling bins and the 2-bins system.

Table 5 Results questionnaire Part D (the effective design of bins in the UKM)

\begin{tabular}{llcc}
\hline & \multicolumn{1}{c}{ Questions } & Answer & Number of Respondents \\
\hline \multirow{2}{*}{ D1 } & Will you open and close the lid when disposing & Yes & 328 \\
& rubbish? & No & 58 \\
\multirow{2}{*}{ D4 } & Do you agree, with the design of the recycle bins & Not Sure & 14 \\
& (Figure 1)? & Nes & 364 \\
\hline
\end{tabular}

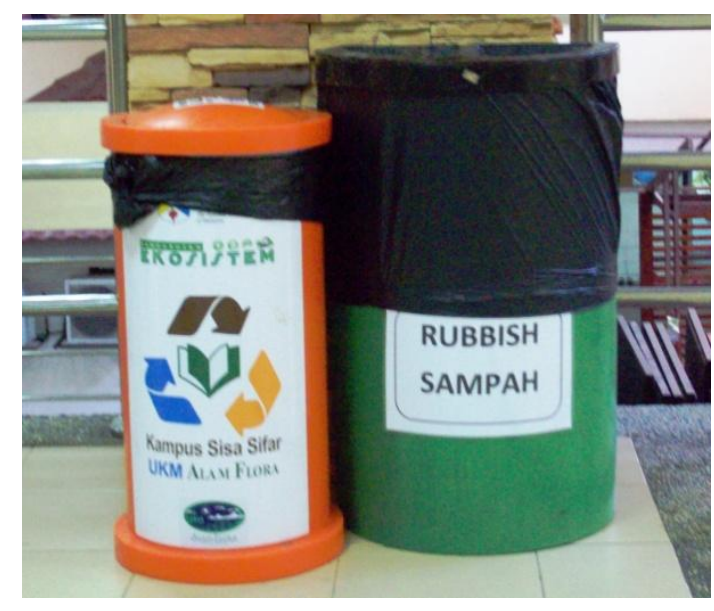

Figure 2 Sample design recycling bins

In addition, the proposed form and colour of the recycling bins are shown in Table 6. Question D3 asked the opinion of the location of the recycling bins. The result shows that the students suggested the recycling bins to be placed in the vicinity 
of UKM such as: (i) The faculty - the back of the building, cafeteria, and in the lecture hall foyer, (ii) In residential college back of the building, next to the toilet, and every level in a building, (iii) The Cafeteria - next to the sink and doorway, (iv) In DECTAR - each entrance and parking, (v) In Pusanika - all levels, food stores, and every entry, and (vi) Each doorway.

Table 6 Results of shapes and colors proposed for the recycling bins (D2)

\begin{tabular}{ccc}
\hline Category & Shape & Color \\
\hline Plastic Bottle & Round & Transparent \\
Glass & Round & Red \\
Textile & Rectangular & Green \\
e-Waste & Round & Yellow \\
Bag Plastic & Rectangular & Black \\
Paper & Rectangular & Green \\
Tetrapak & Triangular & Black \\
\hline
\end{tabular}

\section{CONCLUSIONS}

Recycling knowledge and the $3 \mathrm{R}$ concept were shown to be generally positive in the campus. Awareness of the recycling scheme on the 2-bins system was high and the participation rates showed that the scheme was relatively well supported by students. The questionnaire study could be concluded as shown in below:-

a) Part B evaluation on solid waste management in UKM could be concluded that the 400 respondents were satisfied with the current solid waste management in UKM provided by waste collector contractor which is Alam Flora Sdn. Bhd.. Alam Flora Sdn. Bhd. provides systematic and efficient waste collection system in UKM.

b) Part $\mathrm{C}$ questionnaire was to investigate the level of knowledge and the 3R concept of recycling to students of UKM, it was found that students were very concerned about recycling activities and recycling facilities should be supplied adequately in UKM. Thus, the recycling center and the 2-bins system is needed to encourage and to foster UKM community in recycling activities and to reduce the rate of disposal per day.

c) Part D questionnaire was to find about the design of effective bins in UKM. From the result, respondents mostly agreed with the proposed design which is 2-bins system. This is because the system is simple and easy to use.

Furthermore, there is not much significant difference between male and female throughout all the questionnaires and self-reported recycling behavior from the Pearson Chi Square test. As a conclusion, students indicated that they are ready to start recycling activities in their daily life if recycling facilities are provided with easy accessibility. Hence, UKM management should implement recycling system in solid waste management.

\section{ACKNOWLEDGMENT}

The authors are grateful for the support to this project which was carried out at the Universiti Kebangsaan Malaysia (under research grant UKM-PTS-007-2009, UKM-GUP-PLW-08-13-052, PTS-2012-096 and OUP-2012-051) with cooperation of Alam Flora Sdn Bhd (M).

\section{REFERENCES}

[1] Alam Flora. (2009).Towards a clean environment: A proposal on sustainable and integrated solid waste management system for universiti Kebangsaan Malaysia. Report from Alam Flora.

[2] Oskamp S. Resource conservation and recycling: behavior and policy. J Social Issues 1995;51(4):157-77.

[3] Hamburg KT, Emdad Haque C, Everitt JC. Municipal waste recycling in Brandon, Manitoba: determinants of participatory behaviour. Can Geogr 1997;41(2):149-65.

[4] Kelly T.C. , Mason I.G., Leiss M.W. \& Ganesh S.. University Community Responses to On-campus Resource Recycling. Resources, Conservation and Recycling 47 (2006) 42-55

[5] Mitchell and Jolley. Research Design Explained. Wadsworth, Cengage Learning; 2010.

[6] Greenacre MJ. Theory and applications of correspondence analysis. London, UK: Academic Press; 1984.

[7] Hair JF, Anderson RE, Tatham RL, Black WC. Multivariate data analysis - with readings. 5th ed. New Jersey, USA: Prentice-Hall Inc.; 1998.

[8] Jabatan Pengurusan Sisa Pepejal Negara, JPSPN. (2010). http://www.kpkt.gov.my/jpspn/main.php?Content=sections\&SubSectionID=48\&SectionID=43. [3 Disember 2010] 